\title{
Analisis Tingkat Kepuasan Peternak Plasma Terhadap Pelaksanaan Kemitraan Ayam Broiler PT. Mitratama Karya Abadi (MKA)
}

\author{
Nuzul Azmi'), Bambang Ali Nugroho'), Siti Azizah²) \\ ${ }^{1}$ Mahasiswa Program Pascasarjana Fakultas Peternakan, Universitas Brawijaya, Malang \\ ${ }^{2}$ Dosen Fakultas Peternakan, Universitas Brawijaya, Malang \\ J1. Veteran, Malang 65145 \\ *Email korespondensi: azmi.nuzul@gmail.com
}

(Diterima: 12-11-2018; disetujui 15-12-2018)

\begin{abstract}
ABSTRAK
Kepuasan peternak plasma merupakan faktor penting dalam sistim kerjasama kemitraan ayam broiler antara pihak inti dan plasmanya. Kepuasan peternak plasma terhadap kinerja dari pihak inti merupakan suatu indikator bahwa kerjasama kemitraan telah berjalan ideal sesuai dengan prinsip-prinsip kemitraan. Penelitian ini dilakukan terhadap peternak plasma yang bergabung dengan kemitraan ayam broiler PT. Mitratama Karya Abadi (MKA). Tujuan penelitian ini adalah untuk mengetahui tingkat kepuasan peternak plasma terhadap pelaksanaan kerjasama kemitraan ayam broiler pada PT MKA. Responden terdiri dari karyawan PT. MKA dan 30 orang peternak plasmanya, penentuan responden secara purposive sampling. Analisis data yang digunakan yaitu analisis deskriptif dan analisis kepentingan-kinerja (Importance Performance Analysis). Hasil penelitian menunjukkan bahwa secara keseluruhan peternak plasma PT. MKA puas dengan kinerja dan pelayanan dari pihak inti, hal ini ditandai dengan perolehan nilai CSI sebesar $66,75 \%$. Berdasarkan 15 atribut kemitraan yang dianalisa, terdapat 6 atribut kemitraan yang memiliki tingkat kepentingan yang tinggi dan kinerja dari atribut kemitraan tersebut dinilai masih rendah oleh peternak plasma.
\end{abstract}

Kata kunci: kemitraan, kepuasan peternak plasma, importance performance analysis

\begin{abstract}
The plasma farmer satisfaction is an important factor in the broiler partnership system because it is an indicator that partnership has been running ideally in accordance with the principles of partnership. This study was conducted on the plasma farmer who joined the broiler chicken partnership of PT. Mitratama Karya Abadi. The purpose of this study was to determine the level of plasma farmer satisfaction on the implementation of broiler chicken partnership at PT. Mitratama Karya Abadi. The respondents consisted of employees of PT. Mitratama Karya Abadi and 30 plasma farmers who were determined by purposive sampling. Data analysis used were descriptive analysis and performanceinterest analysis (Importance-Performance Analysis). Overall, the plasma farmer was satisfied with the performance and service from PT. Mitratama Karya Abadi, which was indicated by the CSI value of $66.75 \%$. Based on the 15 attributes of the partnership analyzed, there were 6 partnership attributes which had a high level of importance and their performance was still considered as low by plasma farmers.
\end{abstract}

Keywords: business partnership, plasma farmer satisfaction, importance performance analysis

\section{PENDAHULUAN}

Prospek masa depan usaha peternakan ayam broiler di Indonesia sangat menjanjikan, dimana Indonesia dengan jumlah penduduk keempat terbesar di dunia adalah pasar konsumen terbesar di Asia Tenggara. Peningkatan jumlah penduduk dan peningkatan pendapatan masyarakat ikut memperlebar peluang usaha ayam broiler. Tingkat konsumsi daging ayam broiler di Indonesia yaitu sekitar $12,5 \mathrm{Kg} / \mathrm{kapita} /$ tahun (BPS, 2017) masih sangat rendah dibandingkan dengan negara lain di Asia Tenggara, sehingga menunjukkan masih adanya ruang untuk pertumbuhan dibidang usaha ini. 
Harga daging ayam broiler yang relatif terjangkau dibandingkan dengan jenis daging ternak lainnya sehingga akan menjadi pilihan utama masyarakat untuk memenuhi kebutuhan konsumsi protein hewani. Daging ayam broiler juga memiliki rasa yang cocok bagi selera konsumsi masyarakat Indonesia pada umumnya dan halal dikonsumsi oleh masyarakat Indonesia yang mayoritas muslim (Daryanto, 2009).

Kabupaten Malang merupakan salah satu Kabupaten yang memiliki populasi ayam broiler terbanyak kedua di Provinsi Jawa Timur setelah Kabupaten Lamongan. Populasi ayam broiler di Kabupaten Malang mengalami peningkatan yang sangat signifikan. Pada tahun 2011 populasi ayam broiler di Kabupaten Malang sebanyak 2.666.662 ekor, pada tahun 2016 meningkat menjadi 28.335.754 ekor (BPS, 2016). Pola pengembangan ayam broiler di Kabupaten Malang terdiri dari pola mandiri dan dengan sistem kemitraan.

Usaha peternakan ayam broiler tidak terlepas dari berbagai resiko yang dapat terjadi selama periode pemeliharaannya. Selain resiko produksi, resiko pasar dan fluktuasi harga juga masih menjadi ancaman bagi peternak ayam broiler. Sistem pemasaran yang belum efisien dan harga yang sering berfluktuasi seringkali membuat peternak ayam broiler mengalami kerugian karena harus menjual ayam produksi mereka dibawah harga pokok penjualan (HPP). Permasalahan usaha peternakan ayam broiler lainnya yaitu semakin meningkatnya biaya sarana produksi (pakan, DOC, vaksin dan obatobatan) yang tidak diimbangi dengan peningkatan harga jual ayam dan kestabilan harga. Kondisi ini membuat peternak semakin tidak berdaya, sehingga banyak peternak yang beralih kepola kemitraan untuk menghindari permasalahan seperti yang diuraikan diatas. Salah satu perusahaan kemitraan ayam broiler yang ada di Kabupaten Malang adalah PT Mitratama Karya Abadi (MKA). Perusahaan ini menjalankan pola kemitraan inti plasma dalam menjalankan usahanya. Peternak plasma dari perusahaan ini tersebar diseluruh wilayah Kabupaten Malang. Melihat besarnya potensi dari agribisnis ayam broiler dan tingginya animo peternak untuk bergabung menjadi peternak plasma sehingga membuat banyak perusahan kemitraan baru yang bermunculan di Malang.

Kepuasan peternak plasma menjadi faktor penting yang perlu diperhatikan dalam proses pengembangan usaha kemitraan. Tingkat kepuasan peternak plasma terhadap perusahaan inti akan membawa dampak positif bagi kelangsungan usaha kemitraan. Peternak plasma yang merasa puas dengan perusahaan inti cenderung akan mempertahankan kerjasamanya dengan perusahaan. Menurut Irawan (2003), kepuasan pelanggan adalah perasaan puas yang didapatkan oleh pelanggan karena mendapatkan value dari pemasok, produsen, atau penyedia jasa. Value ini bisa berasal dari produk, pelayanan, sistem, atau sesuatu yang bersifat emosi. Lebih lanjut Irawan (2003), menyatakan bahwa kepuasan pelanggan secara tidak langsung mencerminkan seberapa jauh perusahaan telah merespon keinginan dan harapan pasar. Dalam jangka pendek seringkali tidak terlihat hubungan antara kepuasan pelanggan dengan profitabilitas. Kepuasan pelanggan merupakan strategi yang lebih bersifat defensif sehingga kemampuan untuk mempertahankan pelanggan itulah yang pada akhirnya mempengaruhi profitabilitas dalam jangka panjang.

Ditengah ketatnya persaingan kemitraan dengan banyaknya kompetitor baru yang bermunculan, sudah sepatutnya perusahaan ini memperbaiki kinerja dan pelayanannya kepada peternak plasma agar bisa tetap bertahan ditengah persaingan yang semakin ketat. Atas dasar inilah, analisis tingkat kepuasan peternak plasma PT. MKA perlu untuk dilakukan. Untuk mengetahui sejauh mana kepuasan peternak plasma terhadap pelaksanaan kemitraan pada PT. MKA.

\section{MATERI DAN METODE}

Penelitian dilaksanakan di Kabupaten Malang. Dasar pertimbangan penentuan lokasi penelitian karena Kabupaten Malang merupakan salah satu Kabupaten yang memiliki populasi ayam broiler terbanyak di Provinsi Jawa Timur. Kabupaten Malang juga terdapat banyak perusahaan kemitraan ayam broiler salah satunya yaitu PT. MKA. Waktu pelaksanaan penelitian dimulai dari tanggal 18 Januari sampai dengan tanggal 28 Februari Tahun 2018.

Metode yang digunakan dalam penelitian ini adalah mixed methods. Menurut Creswell yang dikutip dalam Tashakkori \& Teddlie (2010), penelitian campuran merupakan pendekatan penelitian yang mengkombinasikan antara penelitian kualitatif dengan dengan penelitian kuantitatif. Penelitian kualitatif digunakan untuk menjawab permasalahan penelitian bagaimana pelaksanaan pola 
kemitraan pada PT. MKA. Penelitian kuantitatif digunakan untuk menjawab permasalah penelitian tentang tingkat kepuasan peternak plasma PT. MKA.

Responden yang digunakan dalam penelitian ini adalah peternak plasma PT. MKA. Metode penentuan responden yang digunakan secara purposive sampling. Menurut (Arikunto, 2006) purposive sampling dilakukan dengan cara mengambil subyek bukan didasarakan atas strata, random atau daerah tetapi didasarkan atas adanya tujuan tertentu. Kriteria responden yang digunakan dalam penelitian ini adalah peternak plasma yang minimal sudah bermitra dengan PT. MKA selama dua tahun, atau sudah bermitra dengan PT. MKA selama minimal sepuluh proide masa pemeliharaan ayam. Pertimbangan ini digunakan agar responden bisa memberikan penilaian yang obyektif berdasarkan pengalaman mereka.

Penelitian ini menggunakan dua jenis data yaitu data primer dan data sekunder. Data primer dikumpulkan melalui wawancara terstruktur dengan menggunakan kuisioner yang telah dipersiapkan sebelumnya. Data sekunder bersumber dari pihak inti (PT. MKA) dan instansi terkait lainnya.

Analisis data yang digunkan untuk mengetahui tingkat kepuasan peternak plasma Tabel 1. Skor kesesuaian antara tingkat kepentingan dengan kinerja setiap atribut

\begin{tabular}{clccc}
\hline No & \multicolumn{1}{c}{ Atribut Pelayanan Kemitraan } & $\begin{array}{c}\text { Skor } \\
\text { kinerja }\end{array}$ & Skor kepentingan & $\begin{array}{c}\text { Skor kesesuaian } \\
(\%)\end{array}$ \\
\hline 1 & Kecepatan pencairan hasil panen & 54 & 105 & 51,43 \\
2 & Kualitas pakan & 63 & 112 & 56,25 \\
3 & Kualitas DOC & 66 & 109 & 60,55 \\
4 & Harga kontrak pakan & 70 & 106 & 66,04 \\
5 & Kualitas OVK & 71 & 105 & 67,62 \\
6 & Pemberian kompensasi & 59 & 87 & 67,82 \\
7 & Harga kontrak DOC & 79 & 101 & 78,22 \\
8 & Kesesuaian waktu panen & 100 & 116 & 86,21 \\
9 & Jadwal pengiriman sapronak & 91 & 101 & 90,10 \\
10 & Respon terhadap keluhan & 90 & 98 & 91,84 \\
11 & Penerapan standar produksi & 80 & 85 & 94,12 \\
12 & Harga kontrak OVK & 92 & 96 & 95,83 \\
13 & Pemberian bonus & 103 & 107 & 96,26 \\
14 & Frekuensi bimbingan teknis & 85 & 84 & 101,19 \\
15 & Prosedur penerimaan mitra & 100 & 88 & 113,64 \\
\hline
\end{tabular}

\section{Perhitungan Importance Performance Analysis (IPA)}

Analisis tangkat kepentingan dan kinerja atau Importance Performance Analysis (IPA) yaitu dengan metode Importance Performance Analysis (IPA) dan Customer Satisfaction Index (CSI) (Martilla \& James, 1977).

\section{HASIL DAN PEMBAHASAN}

\section{Analisis Kesesuaian Skor Kepentingan Dan Kinerja \\ Tingkat kesesuaian adalah hasil} perbandingan antara nilai kinerja dengan nilai kepentingan. Berdasarkan hasil analisis kesesuaian diketahui bahwa konfirmasi antara kinerja aktual yang diterima peternak plasma dengan harapan peternak relatif belum terpenuhi karena sebagian besar kinerja dari atribut kemitraan PT MKA lebih rendah dibandingkan keinginan peternak plasma. Nilai kesesuaian sebesar 100 persen atau lebih menandakan bahwa atribut yang ada sudah sesuai dengan keinginan peternak. Kondisi yang terjadi pada PT MKA yaitu sebagian besar nilai kesesuaian yang dihasilkan kurang dari 100 persen, hal ini mengindikasikan bahwa pelayanan dari PT MKA masih belum sesuai keinginan peternak plasma. Hasil analisis kesesuaian pada PT. MKA dapat dilihat pada Tabel 1. 
dalam rangka meningkatkan kinerjanya guna mencapai kepuasan peternak plasma. Berdasarkan hasil penelitian, diperoleh nilai rata-rata skor tingkat kepentingan sebesar 3,33. Nilai ini memiliki arti bahwa secara keseluruhan atribut kemitraan yang ada pada PT. MKA dianggap sangat penting oleh peternak plasma. Rataan skor kepentingan dari atribut kemitraan yang ada pada PT. MKA dapat dilihat pada Tabel 2.

Tabel 2. Rataan skor tingkat kepentingan

\begin{tabular}{clc}
\hline No & Atribut Kemitraan & Rata-Rata Skor Kepentingan \\
\hline 1 & Prosedur penerimaan mitra & 2,93 \\
2 & Harga kontrak DOC & 3,37 \\
3 & Kualitas DOC & 3,63 \\
4 & Harga kontrak pakan & 3,53 \\
5 & Kualitas pakan & 3,73 \\
6 & Harga kontrak OVK & 3,20 \\
7 & Kualitas OVK & 3,50 \\
8 & Jadwal pengiriman sapronak & 3,37 \\
9 & Frekuensi bimbingan teknis & 2,80 \\
10 & Kesesuaian waktu panen & 3,87 \\
11 & Respon terhadap keluhan & 3,27 \\
12 & Jangka waktu pencairan hasil & 3,50 \\
13 & Penerapan standar produksi & 2,83 \\
14 & Pemberian bonus & 3,57 \\
15 & Pemberian kompensasi & 2,90 \\
\hline Rata-rata skor kepentingan & 3,33 \\
\hline
\end{tabular}

Berdasarkan penilaian tingkat kinerja, didapatkan hasil bahwa rata-rata skor kinerja dari keseluruhan atribut kemitraan yaitu 2,67. Skor ini memiliki arti bahwa secara keseluruhan peternak plasma sudah puas terhadap kinerja yang diberikan PT. MKA. Rata-rata skor kinerja dari atribut kemitraan yang ada pada dapat dilihat pada Tabel 3 .

Tabel 3. Rataan skor tingkat kinerja

\begin{tabular}{clc}
\hline No & Atribut Kemitraan & Rata-Rata Skor Kinerja \\
\hline 1 & Prosedur penerimaan mitra & 3,33 \\
2 & Harga kontrak DOC & 2,63 \\
3 & Kualitas DOC & 2,20 \\
4 & Harga kontrak pakan & 2,33 \\
5 & Kualitas pakan & 2,10 \\
6 & Harga kontrak OVK & 3,07 \\
7 & Kualitas OVK & 2,37 \\
8 & Jadwal pengiriman sapronak & 3,03 \\
9 & Frekuensi bimbingan teknis & 2,83 \\
10 & Kesesuaian waktu panen & 3,33 \\
11 & Respon terhadap keluhan & 3,00 \\
12 & Jangka waktu pencairan hasil panen & 1,80 \\
13 & Penerapan standar produksi & 2,67 \\
14 & Pemberian bonus & 3,43 \\
15 & Pemberian kompensasi & 1,97 \\
\hline Rata-rata skor kinerja & 2,67 \\
\hline
\end{tabular}


Atribut-atribut kemitraan tersebut selanjutnya dibagi kedalam empat kuadran yang mencerminkan kondisi kepentingan dan kinerja dari masing-masing atribut. Matriks IPA terdiri dari empat kuadran, yaitu kuadran I (Prioritas utama), kuadran II (Pertahankan prestasi), kuadran III (Prioritas rendah), dan kuadran IV
(Berlebihan). Kuadran tersebut dipisahkan oleh titik potong, titik potong ini berasal dari rata-rata nilai kepentingan dan rata-rata nilai kinerja. Atribut kemitraan yang terdapat pada masingmasing kuadran dapat dilihat pada Gambar 1.
Keterangan

1. Prosedur penerimaan mitra

2. Harga kontrak DOC

3. Kualitas DOC

4. Harga kontrak pakan

5. Kualitas pakan

6. Harga kontrak OVK

7. Kualitas OVK

8. Jadwal pengiriman sapronak
9. Frekuensi bimbingan teknis

10. Kesesuaian waktu panen

11. Respon terhadap keluhan

12. Kecepatan pencairan hasil panen

13. Penerapan standar produksi

14. Pemberian bonus

15. Pemberian kompensasi

\section{Kuadran I (Prioritas Utama)}

Atribut-atribut yang terdapat dalam kuadran ini memiliki tingkat kepentingan yang tinggi menurut peternak plasma, akan tetapi kinerja yang diberikan PT MKA masih rendah. Atribut-atribut dalam kuadran ini harus diprioritaskan untuk diperbaiki kinerjanya oleh PT MKA. Atribut yang berada pada kuadran ini terdiri dari kualitas pakan, kualitas DOC, harga kontrak pakan, harga kontrak DOC, kualitas OVK dan kecepatan pencairan hasil panen.

\section{Kuadran II (Pertahankan Prestasi)}

Atribut-atribut yang termasuk dalam kuadran II merupakan atribut-atribut yang diangap penting oleh peternak plasma dan PT MKA telah memberikan kinerja sesuai dengan harapan peternak plasma. Atribut yang termasuk dalam kuadran ini merupakan prestasi dari PT MKA yang harus dipertahankan. Beberapa atribut yang masuk dalam kuadaran ini yaitu jadwal pengiriman sarana produksi, kesesuaian waktu panen dan pemberian bonus.

\section{Kuadran III (Pioritas Rendah)}

Atribut kemitraan yang termasuk dalam kuadran ini memiliki tingkat kepentingan yang rendah bagi peternak dan kinerja PT MKA terhadap atribut ini juga dinilai kurang baik oleh peternak plasma. Meskipun prioritas rendah, PT MKA tetap perlu untuk memperbaiki kinerja dari atribut tersebut untuk mencegah atribut pada kuadran III bergeser ke kuadran I. Jika atribut 
ini bergeser ke kuadran I, maka akan menjadi suatu kelemahan perusahaan. Adapun atribut kemitraan yang terdapat dalam kuadran ini yaitu penerapan standar produksi dan pemberian kompensasi.

\section{Kuadran IV (Berlebihan)}

Atribut-atribut yang terdapat dalam kuadran ini memiliki tingkat kepentingan yang rendah menurut peternak plasma, tetapi memiliki kinerja yang baik, sehingga dianggap berlebihan. Kinerja yang sudah diraih atribut kemitraan pada kuadran IV harus dipertahankan dan tidak perlu ditingkatkan lagi karena hanya akan menyebabkan terjadinya pemborosan sumberdaya. Atribut yang termasuk dalam kuadran ini adalah prosedur penerimaan mitra, harga kontrak OVK, frekuensi bimbingan teknis dan respon terhadap keluhan.

\section{Perhitungan Indeks Kepuasan Peternak} Pengukuran terhadap kepuasan peternak secara keseluruhan didapatkan dengan menghitung Customer Satisfaction Index (CSI), untuk mendapatkan nilai CSI diperlukan nilai rata-rata tingkat kepentingan (Mean Importance Satisfaction/MIS) dan nilai rata-rata tingkat kinerja (Mean Satisfaction Score/MSS). Berdasarkan hasil penilaian yang dilakukan oleh peternak plasma terhadap kinerja PT. MKA diperoleh skor CSI sebesar 66,75 persen. Nilai ini berada pada range 0,66 - 0,80 yang memiliki arti bahwa secara keseluruhan peternak merasa puas atas kinerja yang diberikan oleh PT MKA. Meskipun nilai kepuasan yang diperoleh berada pada range memuaskan dengan nilai 66,75 persen, masih terdapat harapan peternak yang belum terpenuhi oleh pihak inti sebesar 33,25 persen. Hal ini memiliki arti bahwa sistem kemitraan yang dijalankan oleh PT MKA masih belum ideal, karena masih belum sesuai dengan kepentingan dan harapan peternak plasma selaku mitra perusahaan. Hasil perhitungan CSI pada PT. MKA dapat dilihat pada Tabel 4.

Tabel 4. Perhitungan indeks kepuasan peternak

\begin{tabular}{clcccc}
\hline No & \multicolumn{1}{c}{ Atribut Kemitraan } & MIS & WF & MSS & WS \\
\hline 1 & Prosedur penerimaan mitra & 2,93 & 0,06 & 3,33 & 0,20 \\
2 & Harga kontrak DOC & 3,37 & 0,07 & 2,63 & 0,18 \\
3 & Kualitas DOC & 3,63 & 0,07 & 2,20 & 0,16 \\
4 & Harga kontrak pakan & 3,53 & 0,07 & 2,33 & 0,16 \\
5 & Kualitas pakan & 3,73 & 0,07 & 2,10 & 0,16 \\
6 & Harga kontrak OVK & 3,20 & 0,06 & 3,07 & 0,20 \\
7 & Kualitas OVK & 3,50 & 0,07 & 2,37 & 0,17 \\
8 & Jadwal pengiriman sapronak & 3,37 & 0,07 & 3,03 & 0,20 \\
9 & Frekuensi bimbingan teknis & 2,80 & 0,06 & 2,83 & 0,16 \\
10 & Kesesuaian waktu panen & 3,87 & 0,08 & 3,33 & 0,26 \\
11 & Respon terhadap keluhan & 3,27 & 0,07 & 3,00 & 0,20 \\
12 & Jangka waktu pencairan hasil panen & 3,50 & 0,07 & 1,80 & 0,13 \\
13 & Penerapan standar produksi & 2,83 & 0,06 & 2,67 & 0,15 \\
14 & Pemberian bonus & 3,57 & 0,07 & 3,43 & 0,24 \\
15 & Pemberian kompensasi & 2,90 & 0,06 & 1,97 & 0,11 \\
& Jumlah & 50,00 & & & 2,67 \\
\hline \multicolumn{1}{c}{ CSI } & & & 66,75 \\
\hline
\end{tabular}

\section{KESIMPULAN}

dari kemitraan PT MKA, hal ini dicerminkan dari perolehan nilai CSI sebesar 66,75 . Rendahnya nilai CSI ini dikarenakan
Secara keseluruhan peternak plasma sudah merasa puas terhadap kinerja masih terdapat banyak atribut kemitraan dari PT. MKA yang kinerjanya belum sesuai dengan harapan peternak plasma. Beberapa 
atribut tersebut sebagaimana yang terdapat dalam kuadaran I berdasarkan analisis Importance Performace Analysis (IPA). Atribut tersebut antara lain kualitas pakan, kualitas DOC, harga kontrak pakan, harga kontrak DOC, kualitas OVK dan kecepatan pencairan hasil panen. PT. MKA perlu memperbaiki kinerja dari atribut-atribut kemitraan yang masih memiliki kinerja kurang baik menurut peternak plasma. Atribut kemitraan tersebut merupakan atribut yang masuk dalam kuadran I berdasarkan hasil analisis IPA. Pihak inti perlu meningkatkan kepuasan peternak plasma terhadap pelaksanaan kemitraan yang dijalankan oleh pihak inti. Hal ini bertujuan agar sistem kemitraan yang dijalankan oleh pihak inti bisa berjalan secara ideal dan sesuai dengan prinsipprinsip kerjasama kemitraan.

\section{DAFTAR PUSTAKA}

Arikunto, S. 2006. Prosedur Penelitian Suatu Pendekatan Praktik. PT Rineka Cipta. Jakarta.

BPS [Badan Pusat Statistik]. 2016. Berita Resmi Statistik Peternakan 2016. Badan Pusat Statistik. Jakarta.
BPS [Badan Pusat Statistik] Provinsi Jawa Timur. 2016. Populasi Ternak Unggas Menurut Kabupaten/Kota Di Provinsi Jawa Timur. Surabaya

Daryanto, A. 2009. Dinamika Daya Saing Industri Peternakan. IPB Press. Bogor

Irawan, H. 2003. 10 Prinsip Kepuasan Pelanggan. PT ElexMedia Komputindo. Jakarta.

Martilla \& James. 1977. ImportancePerformance Analysis. Journal Of Marketing. 14:77-79.

Palmarudi \& Kasim. 2012. Analisis Tingkat Kepuasan Peternak Dalam Pelaksanaan Kemitraan Usaha Peternakan Ayam Ras Pedaging di Sulawesi Selatan: Studi Kasus di Kabupaten Maros. J. Ilmu dan Teknologi Peternakan. 2(1):50-59

Tashakkori, A. \& C. Teddlie. 2010. Mixed Methodology Mengombinasikan Pendekatan Kualitatif dan Kuantitatif. Pustaka Belajar. Yogyakarta. 